\title{
Correspondence
}

\section{Britain's Rôle in Aerospace}

$\mathrm{S}^{\mathrm{N}}$ NCE my letter in the April JouRnal events of a disturbing nature have occurred on Britain's Aeronautical front.

New Government plans for further rationalisation, nationalisation and the general weakening of our aircraft industry in spite of definite promises to the contrary, have contributed to the anxiety and uncertainty of an already emasculated and sorely vexed community.

Also during this period our Society has held its Centenary Lunch and the SBAC its 50th Anniversary Dinner. Both were important, well-attended convivial occasions but, broadly speaking, complete complacency prevailed at each on Britain's future rôle in Aerospace. This is a matter of supreme importance to the nation. It may be, in fact, the most important material factor in this country's economy on a long-term basis, because it will determine our national position in all transport and communications on this planet, as well as in the exploration of entirely new worlds in space, which within the next 50-100 years will most assuredly happen.

Granted the problems involved have increased enormously since the Second World War and have undoubtedly been greatly exacerbated by the catastrophic mistakes on policy perpetrated by successive Governments, but in the final analysis it is my opinion that neither our Society nor the SBAC in their respective fields have produced the leadership and particularly the guts to stem the tide and maintain our survival in the Aerospace (including Aeronautical) age which is already now upon us. It is not surprising therefore that my suggestions of last April have not borne fruit although undoubtedly duly noted and considered.

I was glad to see the President's report in the August JouRnal on the Council's activities during the past few months, but no matter how conscientious and dignified the official deliberations of the Society on this vital matter may have been, they should not go on indefinitely.

Are members of our Society prepared to stand by for an unspecified time waiting for a public declaration of policy by the Society on this question? Should they not insist upon this being done now, no matter how late it may be?

If it is specific and to the point, which it must be within our constitution it is not likely to please everyone, but that is not the object of the exercise. It is the voice of the majority of the Aerospace professional body which constitutes our Society which should be heard without further delay.

12 th August 1966.

Roy Fedden, Hon. Fellow.

\section{Civil Air Transport Training Board}

$\mathrm{T}$ HE letter in the July JournaL from J. M. Rainbow and G. D. Peacock advances some good points for consideration by the future Civil Air Transport Training Board. Their plea for the elimination of irrelevant material from Maintenance Engineer Apprentice syllabi, and the gearing of this training to the pattern of modern maintenance, is most timely. I would add the following to the four points they submit for the Board's consideration:

1. Careful attention should be given to international trends in Aircraft Maintenance Engineer training, the framework for most countries being based on the ICAO Training Manual, Part 11. As Sir William Hildred reminds us in the same issue of the Journal, air safety is indivisible. Air safety begins in the training schools.
2. Aircraft Maintenance Engineers require a combination of sound theory, manual skill, familiarity with air regulations and airline methods, and practical experience of contemporary aircraft, engines and equipment. Breadth of knowledge and experience concerning a number of overlapping technologies, coupled with sound judgment, is more important than study in depth of a few.specialisations, such as aerodynamics or stress analysis.

3. Training courses have long existed to prepare engineers for inspection or maintenance supervisory duties, the right balance was developed in preSecond World War times by the Royal Air Force at Halton and by Air Service Training at Hamble. With revision to meet modern conditions, this type of training is more suitable than apprentice schemes modelled on practice within the manufacturing side of the industry. Some airlines have inclined too much towards the traditional pattern of apprentice training in Britain, disregarding that this pattern is an uneconomic method of providing skilled artisans for mass production. Hence the hours of lathe work and surface grinding.

4. Five years, the standard duration of apprentice training schemes, is unnecessarily long for producing skilled fitters, machinists or aircraft maintenance engineers. With the assistance of modern training aids, many American technical colleges train aircraft maintenance "mechanics" in eighteen months or two years. I have worked with two ICAOsponsored training schools in developing countries where $2 \frac{1}{2}$ years was found adequate, even though the students were being instructed in a language which was not their own.

5. This type of training is best done in special training colleges, preferably in association with a flying school and an avionics school. Since the facilities required include representative transport aircraft, hangars and specialist workshops, engine test cells, plus the usual classrooms and laboratories, such training will be beyond the means of most County Technical Colleges. There would seem to be a case for pooling the Corporation apprenticeship schemes and establishing an engineering counterpart to the College of Air Training.

6. There is really a need for training two types of Aircraft Maintenance Engineers, the versatile "A", " $B$ " and " $C$ " man for the light aircraft field and that group of specialists intended for integration into the complex organisation of the modern airline. There is enough common ground for training both types in concert for the first one or two years but the last year of training for each would be very different. As an example, the light aircraft man probably does need to use a lathe and be able to weld, but is not concerned with the organisational factors that rule transport aircraft engineering.

7. It is not true that the Air Registration Board does not accept newly-graduated maintenance engineers for Licence examinations, but at this stage of their careers the majority can only meet the experience requirements for one or two light aircraft. Fortunately a more useful qualification is already well established in the United Kingdom, namely the Associate Membership examination of the Society of Licensed Aircraft Engineers and Technologists. This qualification, unlike a licence, is permanent and will not disappear because a particular type of aircraft is removed from the Register. 